Ultra-crushed material was found also in veins. In the field it was impossible to distinguish these from pure pseudotachylite veins.

Field and microscopic evidence has shown that the formation of pseudotachylite was very late in the development of the area.

Before the discovery of pseudotachylite and ultra-crushed rocks along some of the prominent features in the area it was not known what these features reflect. Now it is clear that intense crushing has taken place along these features, even if the lack of good marker horizons makes it difficult to assess the amount of movement in the zones.

\title{
Reference
}

Philpotts, A.R. (1964) Origin of pseudotachylites. Amer. J. Sci., Vol. 262, $1008-1035$.

\section{QUATERNARY DEPOSITS AROUND HOLSTEINSBORG}

\section{Anker Weidick}

The area investigated in 1967 is situated between $66^{\circ} 20^{\prime}$ and $67^{\circ} 10^{\prime} \mathrm{N}, 52^{\circ} 30^{\prime}$ and $54^{\circ} \mathrm{W}$, and is part of the high outer coastal terrain of central West Greenland. The greatest heights - more than $1000 \mathrm{~m}$ - are seen in the northernmost and southernmost parts of the area. These parts are separated by an E-W-running depression around Ikertoq fjord, the western continuation of which is seen offshore in Holsteinsborg Dyb (the Holsteinsborg trough), a submarine canyon $500 \mathrm{~m}$ deep separating Store Hellefiske Banke from Lille Hellefiske Banke. Whilst the banks are thought to be ice margin deposits which accumulated during the ice ages, the Holsteinsborg trough acted during these times as a drainage channel for the Inland Ice. 
The highest Quaternary marine deposits are seen 110-140 m above sea level. Whether these limits are synchronous or metachronous has not yet been clarified. Only at lower levels (below $76 \mathrm{~m}$ ) are shells found allowing radio-carbon dating. The frequent occurrence of shells in the marine deposits below $70 \mathrm{~m}$ furnishes possibilities for correlation and dating of these lower levels over the entire area. The four datings hitherto done (by $\mathrm{H}$. Tauber of the National Museum) indicate a trend of uplift closely resembling that described in detail for the Mestersvig area in East Greenland by Washburn and Stuiver (1962). The strand lines seem to increase in height towards the east but this impression is at present only based on the general occurrence of levels, not on dated levels.

The ice margin deposits found in the area were laid down by the Inland Ice before the "fjord stages" situated farther east (maximum age 9500 B.P.) but later than the Wisconsin-Würm moraines of the banks off West Greenland. The deposits found are characteristically less well delineated than those of the "fjord stages". The moraines in the area seem to be situated in a belt marking a stage in the deglaciation of the area and possibly can be split up into several local phases. This stage is designated the "Taserqat stage".

Local moraines have been observed around present glaciers in the northern Kangerdluarssuk (Kangerdluarssuk ungatdleq). Their ages are unknown but they are older than historical time.

\section{Reference}

Wasburn, A. L. and Stuiver, M. (1962) Radiocarbon-dated postglacial delevelling in North-east Greenland and its implications. Arctic, Vol. 15, 66-73. 